\title{
Glucose metabolite glyoxal induces senescence in telomerase-immortalized human mesenchymal stem cells
}

Simon Asbjørn Larsen ${ }^{1 *}$, Moustapha Kassem ${ }^{2,3}$ and Suresh IS Rattan ${ }^{1}$

\begin{abstract}
Background: Various by-products of the cellular metabolism, such as reactive carbonyl species (RCS) are potentially harmful to cells and tissues, and play a role in many physiological and pathological processes. Among various RCS is the highly reactive dicarbonyl glyoxal (GO), which is a natural physiological metabolite produced by the autooxidation of glucose, and can form covalent adducts known as advanced glycation endproducts (AGE). We have previously reported that $\mathrm{GO}$ accelerates ageing and causes premature senescence in normal human skin fibroblasts.

Results: Using a bone marrow-derived telomerase-immortalised mesenchymal stem cell line hMSC-TERT we have observed that an exposure of cells to $0.75 \mathrm{mM}$ and $1 \mathrm{mM} \mathrm{GO}$ induces irreversible cellular senescence within 3 days. Induction of senescence in hMSC-TERT was demonstrated by a variety of markers, including characteristic cell morphology and enlargement, vacuolisation, multinucleation, induction of senescence associated $\beta$-galactosidase, cell cycle arrest, and increased levels of a cell cycle inhibitor p16. These changes were accompanied by increased extent of DNA breaks as measured by the comet assay, and increased levels of the AGE product, carboxymethyllysine (CML). Furthermore, the in vitro differentiation potential of hMSC-TERT to become functional osteoblasts was highly reduced in GO-treated stem cells, as determined by alkaline phosphatase (ALP) activity and mineralized matrix (MM) formation.

Conclusions: The results of our study imply that an imbalanced glucose metabolism can reduce the functioning ability of stem cells in vivo both during ageing and during stem cell-based therapeutic interventions.
\end{abstract}

\section{Introduction}

The progressive accumulation of molecular damage is a universal characteristic of ageing [1-3]. Among the main causative agents of damage, such as reactive oxygen species (ROS), nutritional metabolites and biochemical infidelity, the nutritional metabolites are an important source of molecular damage. For example, an imbalance in the intracellular glucose metabolism leads to increased levels of its oxidative breakdown products dicarbonyls glyoxal (GO), methylglyoxal (MGO), 3-deoxyglucosone (3-DG) and glucosone. These byproducts of cellular metabolism belong to the chemical group of $\alpha$-oxoaldehydes but are more commonly classed as reactive carbonyl species (RCS)

\footnotetext{
* Correspondence: SAL@mb.au.dk

${ }^{1}$ Laboratory of Cellular Ageing, Department of Molecular Biology and Genetics, Aarhus University, Aarhus, Denmark

Full list of author information is available at the end of the article
}

[4]. Besides being a natural physiological metabolite in the auto-oxidation of glucose, GO can alternatively be formed by lipid peroxidation, the degradation of glycated proteins and DNA oxidation among other reactions [4-9]. GO is also present in food and beverages, and is an increasingly used industrial chemical $[7,10,11]$. The highly reactive carbonyl groups of GO can react with lysine, arginine and cysteine residues of proteins to form covalent adducts known as advanced glycation end-products (AGE), associated with the browning and fluorescence of proteins $[4,5,12]$. The accumulation of AGE-damaged proteins by the carbonyl stress of RCS has been implicated in several age-related pathologies, such as Alzheimer's disease, atherosclerosis, kidney failure, cataract and diabetes [8,13-15]. The cellular damage induced by GO and other RCS is not only limited to the proteome but may also harm the genome and the lipome by various means $[7,8,16-18]$. 
We have previously reported that exposures to $1 \mathrm{mM}$ GO or $400 \mu \mathrm{M}$ MGO leads to accelerated ageing and the appearance of senescent phenotype within 3 days in normal human skin fibroblasts $[19,20]$. Ageing and the senescent phenotype in skin fibroblasts were demonstrated by several well established criteria [3], including morphological phenotype, irreversible growth arrest and $G_{2}$ cell cycle arrest, increased senescence-associated $\beta$ galactosidase (SABG) activity, increased $\mathrm{H}_{2} \mathrm{O}_{2}$ level, increased $\mathrm{N} \varepsilon$-(carboxymethyl)-lysine (CML) level, and altered activities of superoxide dismutase and catalase antioxidant enzymes. We have now utilized this experimental model of induced cellular senescence in vitro for testing the effects of GO on other cell types, especially the mesenchymal stem cells (MSC), which are multipotent stem cells capable of differentiating into a variety of cell types, such as osteoblasts, adipocytes, chondrocytes, myocytes, neuron-like and endothelial-like cells [21,22].

Here we report the results of our studies on the effects of GO on growth characteristics, macromolecular damage, induction of senescence and reduced differentiation ability of telomerase-immortalised human bone marrow-derived MSC, designated hMSC-TERT [21]. The aim of these studies was to determine how the imbalanced glucose metabolism observed in vivo during ageing and age-related diseases, such as diabetes-2, may have deleterious effects on the survival and differentiation capacity of MSC. Furthermore, this experimental model of a rapid induction of senescence in immortalized cells provides a reproducible and practical approach for future studies on basic molecular mechanisms of ageing and on testing potential interventions.

\section{Experimental}

\section{Chemicals, antibodies and kits}

1 $\alpha$,25-Dihydroxyvitamin D3 (Vit-D, calcitrol; Sigma \#D1530), $\beta$-glycerophosphate (CALBIOCHEM \#35675), agarose, Low melting point (LMP; Sigma \#A9414), Alizarin Red S (Sigma-Aldrich \#A5533), alkaline phosphatase (Sigma \#P-5931), L-ascorbic acid (Sigma \#A4544), p-nitrophenol phosphate (Sigma-Aldrich \#N3002), pnitrophenol standard solution $10 \mathrm{mM}$ (Sigma \#N7660), propidium iodide (PI; Fluka \#81845), RNase A, Bovine Pancreas (Roche \#10109169001), mouse anti-CML (IgG1; Biologo \#CML011), mouse anti-human p16 ${ }^{\text {INK4a }}$ (IgG1; BD-Pharmingen \#51-1325GR), polyclonal rabbit anti-mouse immunoglobins, FITC-conjugated (IgG; DAKO \#F0232), protein assay $\mathrm{D}_{\mathrm{C}}$ (BIO-RAD \#500-0112) and senescence cells staining kit (Sigma \#CS0030).

\section{Cell culture and GO treatment}

The cell line used in this study was created by a stable retroviral transduction of human bone marrow-derived mesenchymal stem cells with the catalytic subunit of telomerase with reverse transcriptase activity [21]. The cell line (designated hMSC-TERT) exhibits all known characteristics of bone marrow-derived MSC in vitro and in vivo, and displays an extended lifespan [22].

hMSC-TERT was incubated at $37^{\circ} \mathrm{C}, 5 \% \mathrm{CO}_{2}, 95 \%$ atmospheric air and 95\% humidity, and were serially passaged at a split ratio of 1:4. The complete normal DMEM culture media contained $2 \mathrm{mM}$ L-glutamine, 4.5 g/L glucose, $10 \%(\mathrm{v} / \mathrm{v})$ bovine fetal calf serum (FCS), $100 \mathrm{U} / \mathrm{mL}$ penicillin and $100 \mu \mathrm{L} / \mathrm{mL}$ streptomycin. At about $90 \%$ confluency the cell cultures were split using the trypsin/EDTA method. All experiments were performed at population doubling (PD) levels between 52 and 145. Unless otherwise stated, the medium was changed every three days, cells were seeded with a density of 5200 cells $/ \mathrm{cm}^{2}$ and the cells were always allowed to grow for $24 \mathrm{~h}$ after seeding before any treatments with $\mathrm{GO}$ was given. The duration of GO treatment was 3 days unless otherwise noted. Cell viability was determined by MTT assay, which showed that doses of up to $1 \mathrm{mM}$ GO were not cytotoxic, but at higher doses, the cells would shrink and die in less than $24 \mathrm{~h}$ (data not shown).

\section{Cellular growth analysis}

Cells used for the 10-day survival analysis were seeded in several 12-well plates with 8,000 cells per well $(\sim 2100$ cells $/ \mathrm{cm}^{2}$ ) in normal medium. After $24 \mathrm{~h}$, the culture medium was replaced with either fresh normal medium or the medium containing $0.75 \mathrm{mM} \mathrm{GO}$ or $1 \mathrm{mM}$ GO. The treatment was continued either for 10 days or for 3 days followed by the replacement of the GO-containing medium with the normal medium for the remaining 7 days. Three replicates of wells for each condition were trypsinized and counted after 1, 3, 5, 7 and 10 days of treatment. Cell counting was performed in triplicates, using a Bürker-Türk hemocytometer.

\section{Cellular morphology analysis}

The cells were seeded in a 6-well plate with 50,000 cells per well $\left(\sim 5200\right.$ cells $\left./ \mathrm{cm}^{2}\right)$. After $24 \mathrm{~h}$ the cells were treated with various doses of GO for 3 days and then observed for morphological appearance, using a phasecontrast microscope. The cell size distribution was determined by FACS analysis. The senescence-associated $\beta$-galactosidase (SABG) assay was performed using the histochemical staining kit from Sigma-Aldrich [23].

\section{Cell cycle analysis by PI staining and flow cytometry}

The cells were seeded in a 6-well plate, and after $24 \mathrm{~h}$ treated with various doses of GO for 3 days. The cells were trypsinized, resuspended in $1 \mathrm{~mL}$ normal medium before centrifugation at $300 \times \mathrm{g}$ for $5 \mathrm{~min}$, and the supernatant was carefully removed in order not to 
disrupt the fragile pellet. The cells were fixed in $70 \%$ cold ethanol for $1 \mathrm{~h}$ at $4^{\circ} \mathrm{C}$, were centrifuged again and were resuspended in $1 \mathrm{~mL}$ PBS. In order to degrade any double stranded RNA before the PI staining, $100 \mu \mathrm{L}$ RNase A $(100 \mu \mathrm{g} / \mathrm{mL})$ was added and the cells incubated for $15 \mathrm{~min}$ at $37^{\circ} \mathrm{C}$ without $\mathrm{CO}_{2}$. Thereafter, $400 \mu \mathrm{L}$ PI $(50 \mu \mathrm{g} / \mathrm{mL})$ was added and the cells were incubated for $1 \mathrm{~h}$ at room temperature (RT) in dark. During the flow cytometry analysis the cells were sorted from debris by FSC and SSC gating and any doublets were sorted out by pulse processing by using the PI-height and PI-area. The data were collected in linear scale and the percentage of cells in different cell cycle phases was defined by Watson pragmatic model fit by Flow Jo (Tree star Inc.)

\section{p16 and CML detection by immunofluorescence and flow cytometry}

The cells were seeded in 6-well plates, and after $24 \mathrm{~h}$ the cells were treated with various doses of $\mathrm{GO}$ for 3 days. The cells were trypsinized and resuspended in 1 $\mathrm{mL}$ wash buffer (PBS with 5\% FCS) before centrifugation at $600 \mathrm{~g}$ for $5 \mathrm{~min}$, fixed first in $150 \mu \mathrm{L} 0.25 \%$ PFA for $20 \mathrm{~min}$ at $4^{\circ} \mathrm{C}$ then washed twice and fixed again with $150 \mu \mathrm{L} 70 \%$ cold methanol for $1 \mathrm{~h}$ at $4^{\circ} \mathrm{C}$, washed and then permeabilised with $150 \mu \mathrm{L} 0.25 \%$ Triton $\mathrm{x}-100$ for $5 \mathrm{~min}$ on ice, washed again before incubating for 30 min at RT with primary antibody. For p16 detection 100 $\mu \mathrm{L}$ of 1:10000 mouse anti-human $\mathrm{p} 16^{\mathrm{INK} 4 \mathrm{a}}$ was used in $10 \%$ FCS-PBS to a final concentration of $25 \mathrm{ng} / \mathrm{mL}$. For CML detection, the mouse anti-CML was diluted $1: 10000$ in $10 \%$ FCS-PBS to a final concentration of 25 $\mathrm{ng} / \mathrm{mL}$. The cells were washed twice before adding 100 $\mu \mathrm{L}$ solution of the FITC-conjugated secondary antimouse antibody and incubated $30 \mathrm{~min}$ at RT in dark. The secondary antibody was diluted 1:40 in 10\% FCSPBS, according to manufacturer's recommendations, resulting in the final concentration of $75 \mu \mathrm{g} / \mathrm{mL}$. The cells were washed and resuspended in $1 \mathrm{~mL}$ wash-buffer and were analysed immediately by flow cytometry, as described above. The data are presented as geometric mean values of fluorescence intensity, as collected on a logarithmic scale, and the CV (coefficient of variation (CV) representing the peak width are included.

\section{Comet assay}

This variant of the assay was as modified by Singh et al. 1988 [24]. The cells were seeded in a 6-well plate, and after $24 \mathrm{~h}$ the cells were treated with various doses of $\mathrm{GO}$ for $24 \mathrm{~h}$ or 3 days. The positive controls were prepared by adding $0.2 \mathrm{mM} \mathrm{H}_{2} \mathrm{O}_{2}$ for $20 \mathrm{~min}$. After treatment, the cells were trypsinized and counted, and 50,000 cells from each sample were resuspended in 1 $\mathrm{mL}$ PBS and centrifuged for $1 \mathrm{~min}$ at $1000 \mathrm{~g}$. The supernatant was removed and the cells were resuspended in
$100 \mu \mathrm{L}$ low melting point (LMP) agarose, which had been melted and maintained at $37^{\circ} \mathrm{C}$ in water-bath before use. $75 \mu \mathrm{L}$ of this LMP agarose cell-suspension was added on top of previously prepared normal melting point (NMP) agarose slides. The thin NMP agarosecoating reduces the chance of the LMP agarose layer to fall off during the procedure. The cell-suspension was added very quickly before the LMP agarose hardened. A coverslip was added on top and the slides were placed at $4^{\circ} \mathrm{C}$ for $10 \mathrm{~min}$ for agarose to harden. The coverslips were gently removed and the slides submerged in lysis solution (2.5 M NaCl, $100 \mathrm{mM} \mathrm{Na}{ }_{2}$ EDTA, $10 \mathrm{mM}$ Tris base, $\mathrm{pH} 10$ ) at $4^{\circ} \mathrm{C}$ for $2 \mathrm{~h}$ and kept in dark. The slides were gently rinsed in water and placed in electrophoresis buffer (300 mM NaOH, 1 mM Na 2 EDTA, pH > 13) at $4^{\circ} \mathrm{C}$ for $40 \mathrm{~min}$ to allow unwinding. The electrophoresis was done at $15 \mathrm{~V}(0.8 \mathrm{~V} / \mathrm{cm})$ and $300 \mathrm{~mA}$ at $4^{\circ} \mathrm{C}$ for $20 \mathrm{~min}$. The slides were gently washed three times in neutralization buffer (0.4 M Tris base, $\mathrm{pH} 7.5)$ for 5 min and then dehydrated twice in $100 \%$ ethanol for 5 min at RT. $20 \mu \mathrm{L}$ ethidium bromide $(10 \mathrm{mg} / \mathrm{mL})$ was added to each sample and coverslips applied. The extent of DNA damage was evaluated under UV light by using a fluorescence microscope, and several pictures were taken to represent at least 50 cells per sample from different areas on the slide. Cells near the slide-edges were avoided due to electrophoresis-distortion in these areas. The pictures were analyzed by image analysis software (AutoComet Cometscore Freeware version 1.5 of Tritek Corporation). The cutoff value was adjusted to avoid saturation but kept constant in all samples. The full length and the head-centre of each comet were designated by a drag-box and the percentage of DNA in each comet tail quantified by the software.

\section{Alkaline phosphatase activity assay}

An established marker for osteoblastic differentiation is the expression and activity of alkaline phosphatase (ALP) after treatment with Vit-D or calcitrol [22]. The cells were seeded in T25 flasks with 52,000 cells per flask $\left(\sim 2100\right.$ cells $\left./ \mathrm{cm}^{2}\right)$. After $24 \mathrm{~h}$ the cells were treated with various doses of GO for 3 days. The cells were trypsinized, counted and reseeded in 12-well plates with precisely 8,000 cells per well $\left(\sim 2100\right.$ cells $\left./ \mathrm{cm}^{2}\right)$. Preliminary experiments showed that this reseeding step for cells was necessary to avoid crowding in order for optimum ALP detection. After $24 \mathrm{~h}$ the normal medium was replaced with medium containing Vit-D $\left(10^{-8} \mathrm{M}\right)$. The cells were cultured for 7 days after which two of the three replicates were used for the ALP assay and one was used for protein quantification.

The ALP activity was measured by washing the cells twice with PBS, adding $250 \mu \mathrm{L}$ alkaline buffer solution per well, and incubating the cells for $10 \mathrm{~min}$ at $37^{\circ} \mathrm{C}$ to 
increase the pH. $250 \mu \mathrm{L}$ of ALP substrate solution (5 mM pNPP diluted in alkaline buffer solution) was added and the plates incubated for $30 \mathrm{~min}$ at $37^{\circ} \mathrm{C}$. The commercial ALP used for a standard curve had been subdiluted in the range from $5 \times 10^{-5} \mathrm{U} / \mu \mathrm{L}$ to $6.25 \times 10^{-8}$ $\mathrm{U} / \mu \mathrm{L}$ in $200 \mu \mathrm{L}$ of the same substrate solution and incubated in a 96-well plate, simultaneously with the samples. Two aliquots of $200 \mu \mathrm{L}$ from each well were transferred to the 96-well plate and the plate was read in a microplate reader at $A_{415} \mathrm{~nm}$ with $A_{595} \mathrm{~nm}$ as a reference. To level out the difference in density from the GO induced growth arrest, the average ALP activity from each replicate was related to the corresponding cellular protein concentration in the samples.

\section{Mineralised matrix assay}

Mineralised matrix (MM) is formed during osteoblastic differentiation when the osteoblasts mineralise. In this modified assay, MM formation was induced by incubating the cells for 10 days with complete DMEM containing 50 $\mu \mathrm{g} / \mathrm{mL} \mathrm{L}$-ascorbic acid, $10 \mathrm{mM} \beta$-glycerophosphate, and $10^{-8} \mathrm{M}$ Vit-D (MM culture conditions) [22]. The presence of calcium was detected by staining with the dye Alizarin Red $\mathrm{S}$ which binds selectively to calcium salts. The cells were seeded in 12-well plates with 8,000 cells per well $\left(\sim 2100\right.$ cells $\left./ \mathrm{cm}^{2}\right)$. After $24 \mathrm{~h}$ the cells were treated with various doses of GO for 3 days then the medium was changed for the MM culturing medium. The Alizarin red $\mathrm{S}$ staining was performed by washing the cells three times with $\mathrm{PBS}$, fixing with $70 \%$ ethanol for $1 \mathrm{~h}$ at $-18^{\circ} \mathrm{C}$, washing with $\mathrm{dH}_{2} \mathrm{O}$ and staining with $0.5 \mathrm{~mL} 40 \mathrm{mM}$ Alizarin Red S, pH 4.2 (dissolved in $\mathrm{dH}_{2} \mathrm{O}$ ) for $1 \mathrm{~h}$ at RT on a shaker. The cells were washed thoroughly five times with $\mathrm{dH}_{2} \mathrm{O}$ to remove unspecific staining and incubated in $10 \%$ (wt/vol) cetylpyridinium chloride (CPC) (dissolved in $\mathrm{dH}_{2} \mathrm{O}$ ) for $1 \mathrm{~h}$ to elute the stain. The absorbance of the eluted stain was measured in $200 \mu \mathrm{L}$ aliquots in a microplate reader at $\mathrm{A}_{595 \mathrm{~nm}}$ and related with an Alizarin Red $\mathrm{S}$ standard curve of 0-10 mM sub-dilutions in 10\% CPC. All samples were within the linear interval of the standard curve. The values from each condition was normalised with the corresponding cellular protein concentration from the sample, and the data were presented as mM Ali-

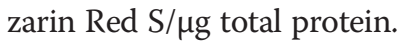

For protein quantification the cells were lysed by a CHAPS-based lysis buffer and the protein was estimated by the $\mathrm{D}_{\mathrm{C}}$ Protein Assay kit from BIO-RAD according to manufacturer's protocol. All samples were related with a standard curve of BSA subdilutions in the range of $0-2 \mathrm{mg} / \mathrm{mL}$.

\section{Statistical analysis}

All statistical analysis in this study were performed by Student's paired $t$-test, as the compared cell populations are considered to be matched since they have the same origin. Figures marked with single or double asterisks indicate significant different groups from the control indicated in the figure legend, ${ }^{*}=\mathrm{p}<0.01,{ }^{* * *}=\mathrm{p}<0.05$.

\section{Results}

\section{Induction of cellular senescence in hMSC-TERT}

Exposure of telomerase immortalized hMSC-TERT cells to GO resulted in the induction of senescence within 3 days, as judged by several criteria. The selection of GO doses $(0.75 \mathrm{mM}$ and $1 \mathrm{mM})$ was made on the basis of a MTT assay performed on hMSC-TERT and on our previously published results on human skin fibroblasts $[19,20]$. Figure 1 shows that GO-treated cells attained typical in vitro senescent cell morphology in terms of becoming significantly large, irregular, flattened, vacuolated, multinucleated and heterogeneous. Although these morphological changes could also be seen in cells treated with $0.75 \mathrm{mM} \mathrm{GO}$, the effects were more dramatic after treatment with $1 \mathrm{mM}$ GO (Figure 1, upper panel). Furthermore, this GO-induced senescent phenotype was maintained even after the removal of GO during the follow up period of 3 days (Figure 1, lower panel). The increased heterogeneity of the cellular size was obvious in cell suspension (Figure 2, upper panel), and was further confirmed and quantified by flow cytometry (Figure 2, lower panel). There was a clear increase in the proportion of large cells within a cell population with increasing doses of $\mathrm{GO}$, as measured by the shift in the mean value of the forward scatter. Average cell size was also quantified using an automated cell counter (Countess ${ }^{\circledR}$, Invitrogen). After 3 days of GO treatment the average cell sizes were $21.8 \mu \mathrm{m}, 23.7 \mu \mathrm{m}$ and 28.7 $\mu \mathrm{m}$ for the control, $0.75 \mathrm{mM}$ and $1 \mathrm{mM}$ GO-treated cells, respectively (data not shown).

Another cellular biomarker of senescent cells is the increase in the senescence associated $\beta$-galactosidase (SABG) activity [23]. The number of SABG-positive cells was counted among at least 500 cells in each sample in two independent experiments. Figure 3 shows that there was a several fold increase in the number of SABG-positive cells after GO-treatment for 3 days (4.5and 9.2-fold increase for $0.75 \mathrm{mM}$ and $1 \mathrm{mM}$ GO, respectively).

The effect of GO on growth rate was determined by a 10 -day cell growth assay where the cells were treated either continuously or only during the first 3 days with $0.75 \mathrm{mM}$ and $1 \mathrm{mM}$ GO. Figure 4 shows that whereas the number of cells in untreated control cultures increased about a hundred-fold during the 10-day period, a continuous treatment with GO resulted in an almost total inhibition of cell growth and proliferation during this period. However, if the GO treatment was limited to 3 days followed by replacement with normal 

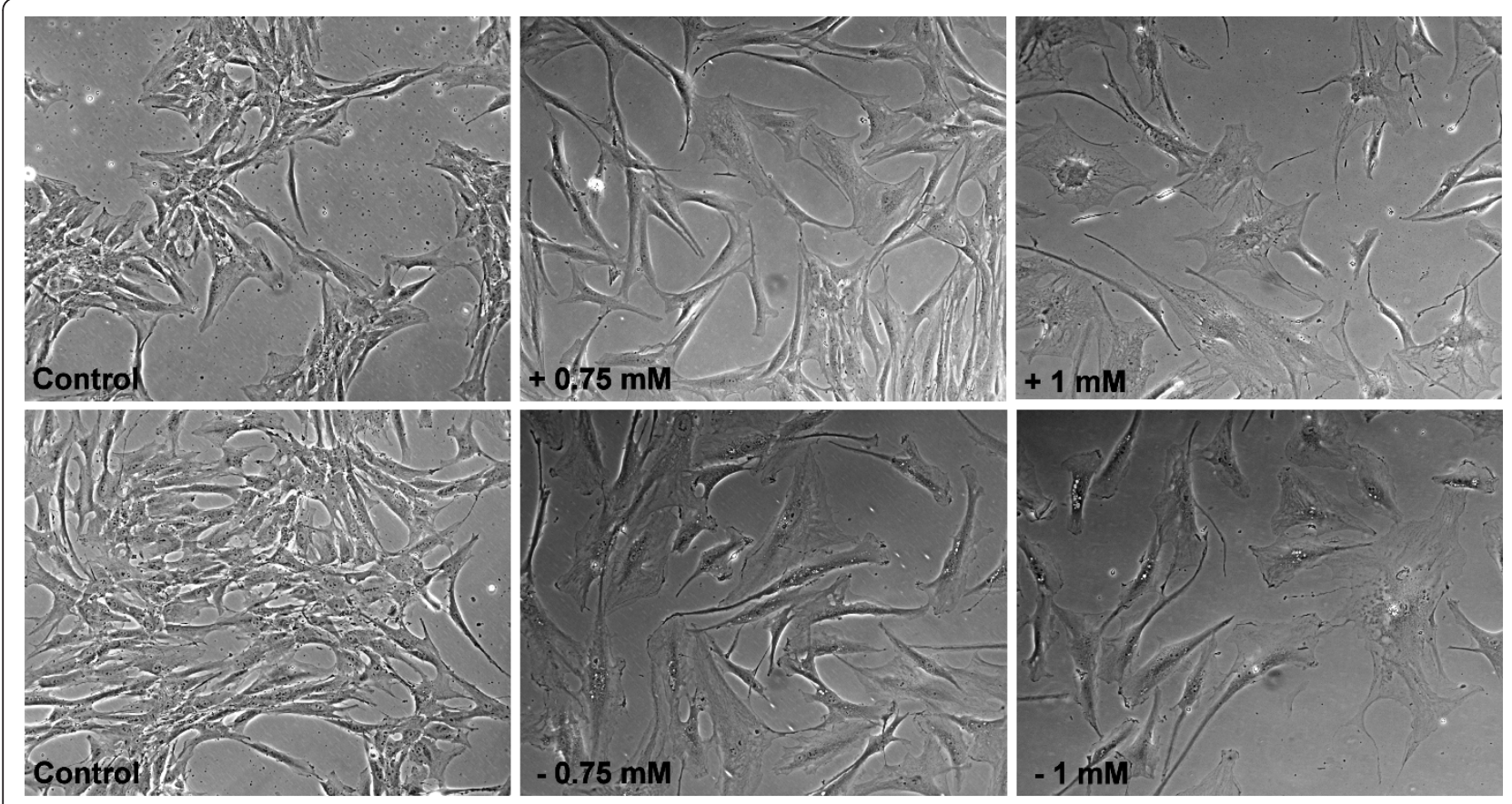

Figure 1 Cellular morphology of hMSC-TERT after GO treatment. The upper panel shows cell enlargement, vacuolation and an increased heterogeneity after 3 days of treatment with $0.75 \mathrm{mM}$ and $1 \mathrm{mM} \mathrm{GO}$. The lower panel shows that after 3 days of GO treatment, followed by 3 days in normal medium without $\mathrm{GO}$, the treated cells did not revert back to the normal morphology and maintained a senescent appearance. Pictures were taken using a $10 \times$ objective lens on a phase-contrast microscope.
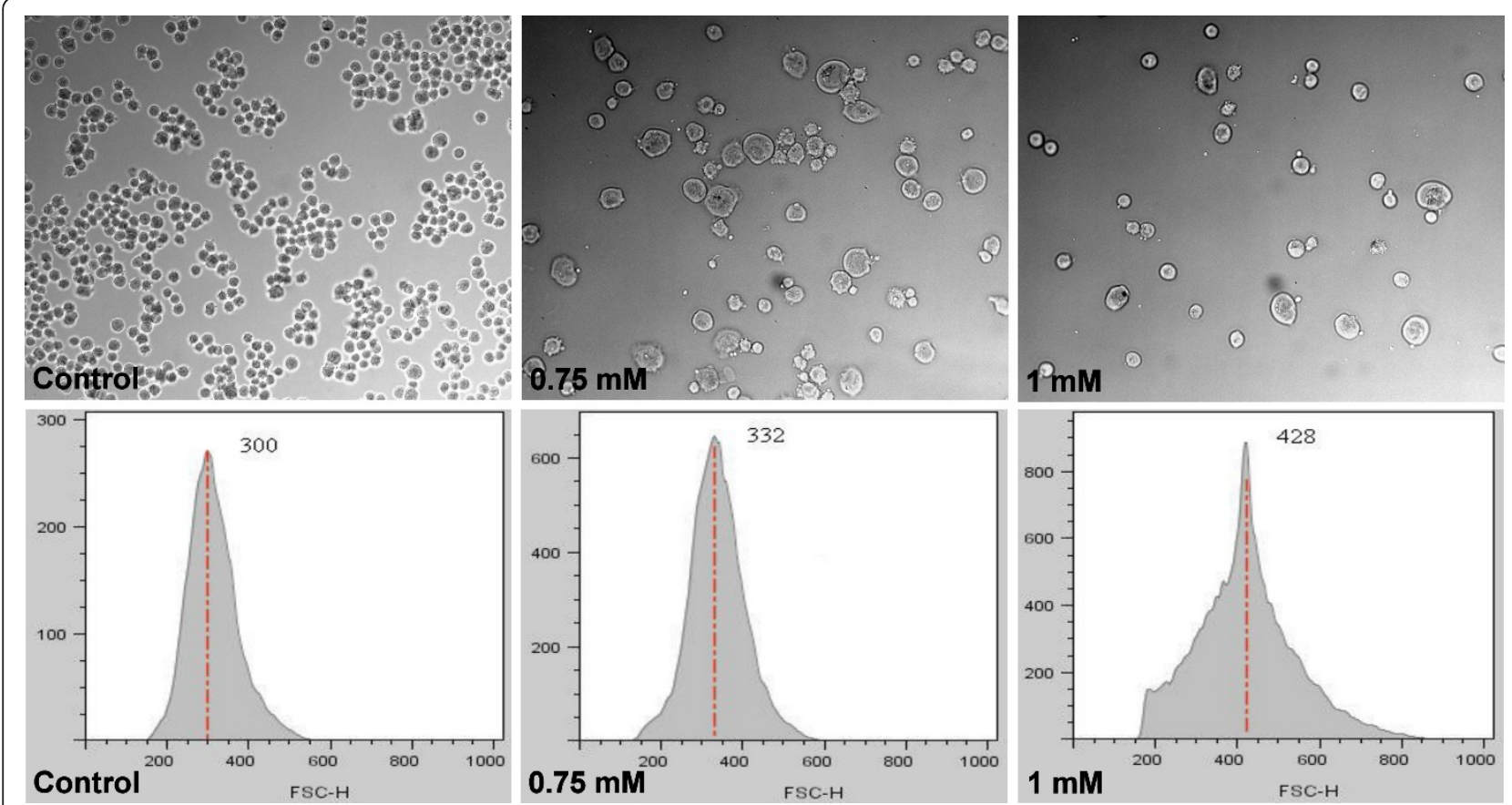

Figure 2 Increase in hMSC-TERT cell size and heterogeneity with GO treatment in suspension (upper panel, 10x objective lens), and confirmed by FACS analysis (lower panel). The increase in the average value of the forward scatter with GO treatment indicates an increase in average size. The coefficient variation (CV) was $16 \%, 17 \%$ and $24 \%$, respectively. 


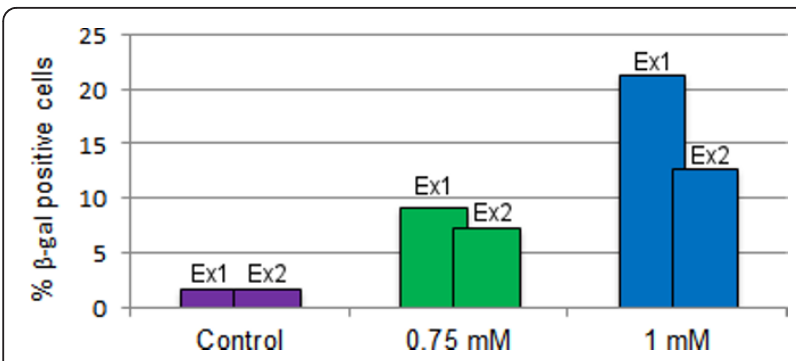

Figure 3 Percentage of senescence associated $\beta$-galactosidase (SABG) positive hMSC-TERT after 3 days of GO treatment. Data from two independent experiments are presented as Ex1 and Ex2, respectively.

culture medium, there was some increase in cell number in $0.75 \mathrm{mM}$ treated cultures, but almost no increase in 1 $\mathrm{mM}$-treated cultures, during the following 7 days. It is not clear if the recovery in growth of $0.75 \mathrm{mM}$-treated cultures after 7 days is due to a sub-set of resistant cells or whether all cells were able to recover from GOinduced cell growth inhibition after removal of GO.

Another parameter and biomarker of cellular senescence in vitro is the cell cycle arrest dynamics including an increased level of cell cycle inhibitor p16 [25]. We have analysed the cell cycle distribution and the levels of p16 of GO-treated and untreated hMSC-TERT by immunofluorescence and FACS analysis. This experiment does not distinguish between the normal dividing cells in the $G_{1}$ phase of the cell cycle and those which have entered irreversible $G_{0}$. The distribution of phases by the Watson Pragmatic model was determined by

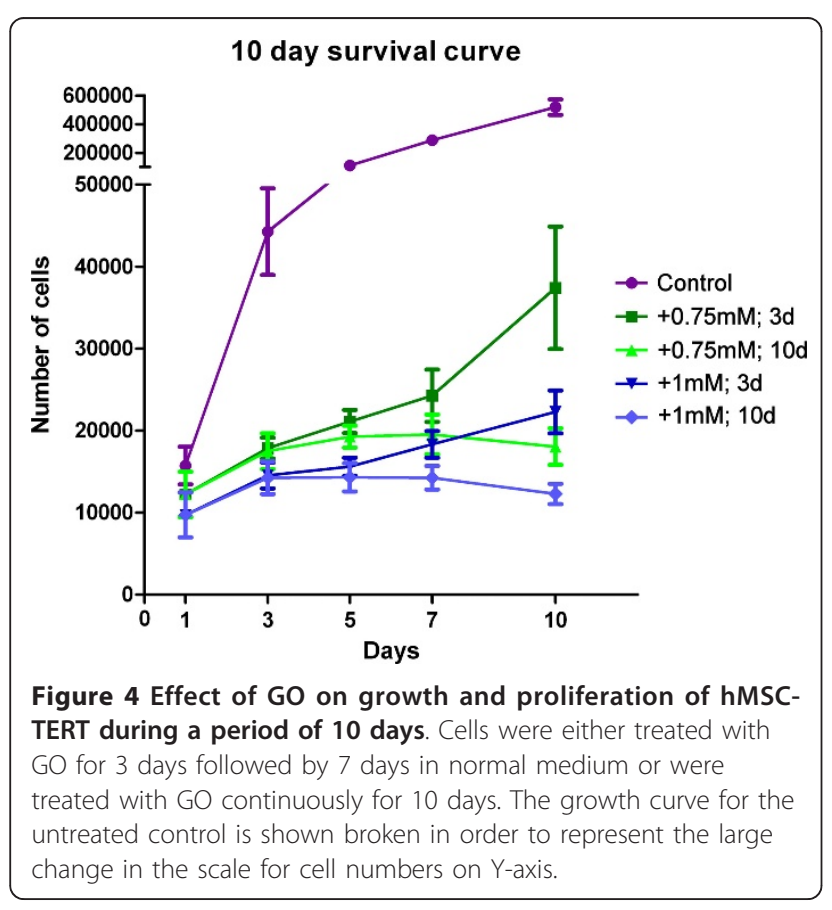

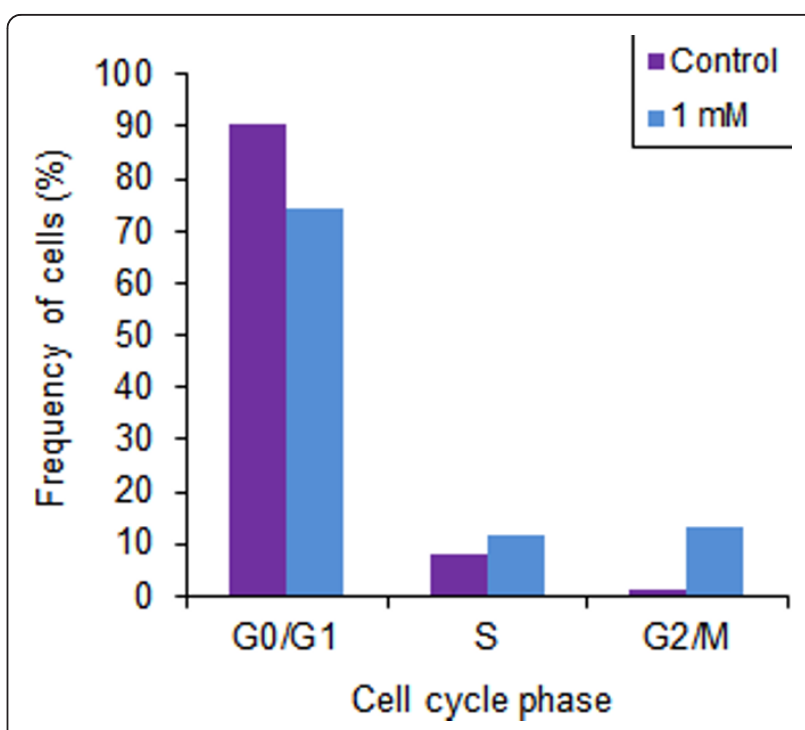

Figure 5 Frequency (\%) of cells in different phases of the cell cycle in untreated control and in GO-treated hMSC-TERT cells ( 3 days, $1 \mathrm{mM}$ ). The frequency is calculated by the Watson pragmatic fit model by the Flow-Jo software according to the $2 \mathrm{n}$ and $4 \mathrm{n}$ peaks from a histogram relating the PI fluorescence with cell number.

flow cytometry analysis software after PI staining. The cells were gated by their FSC and SSC to represent the main population and to avoid debris. Hereafter they were pulse processed to avoid cell aggregates by gating according to the area (FL2-A) and width (FL2-W) of the pulse signal from the fluorescence detector (not shown). To distinguish between the $2 \mathrm{n}$ and $4 \mathrm{n}$ DNA content in the cells, the characteristics of PI fluorescence (FL2-H) were related with cell number and the percentage of cells in each phase was calculated according to the Watson pragmatic fit model by Flow-Jo software [26].

Figure 5 shows that $1 \mathrm{mM}$ GO treatment caused the growth arrest in hMSC-TERT cells as the frequency of cells in G2/M-phase increased from $1.33 \%$ to $13.26 \%$. A slight increase in the frequency of cells in the S-phase was not caused by an increased number of cells entering into this phase (as also observed with the reduced growth rates), but rather it indicates that the S-phase progression is severely delayed [27]. The observed growth arrest in GO-treated cells was further supported by the observation that the levels of the cell cycle check point marker p16 increased by $61 \%$ in hMSC-TERT cells treated with $0.75 \mathrm{mM}$ and $1 \mathrm{mM}$ (Figure 6).

\section{Induction of macromolecular damage in hMSC-TERT by GO}

The extent of DNA damage induced by GO was determined by the comet assay, which measures the prevalence of single- and double-strand breaks. The level of DNA damage was estimated from the percentage of DNA in the 


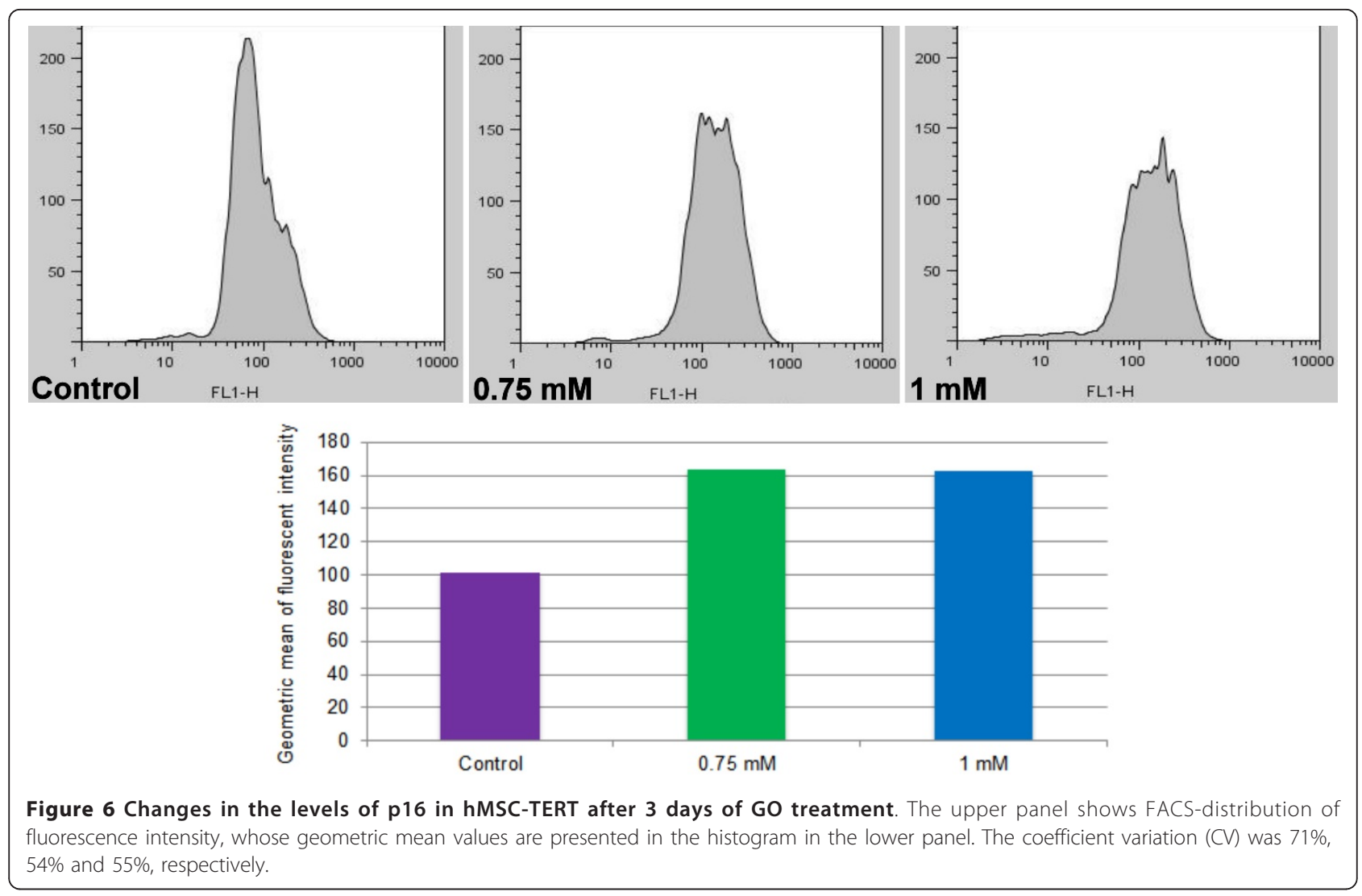

tails of the comets formed after the single-cell gel electrophoresis as broken DNA moves faster in the current (Figure 7). The percentage of DNA in the tails versus the core was analyzed by Tritek Cometscore Freeware version 1.5., and the results show that hMSC-TERT cells treated with GO for 3 days had significantly higher levels of damaged DNA than the untreated cells (Figure 8). As the positive control, DNA damage was induced in the cells by treatment with $0.2 \mathrm{mM} \mathrm{H}_{2} \mathrm{O}_{2}$ for $20 \mathrm{~min}$. All samples were significantly different from the untreated controls as calculated by Student's paired $t$-test.
Ne-Carboxymethyl-Lysine (CML) adducts are the most prevalent form of AGEs, and previous studies have shown that CML adduct formation is induced by GO [28]. The levels of CML adducts was determined in two independent experiments, using immunofluorescence and flow cytometry. Figure 9 (upper panel) shows the fluorescence intensity distribution from one experiment, and the histogram (lower panel) shows the geometric mean values of the fluorescence intensity in GO-treated and control cells from the same experiment. There was about a 2 -fold increase in CML adducts in GO-treated hMSC-TERT in both experiments.
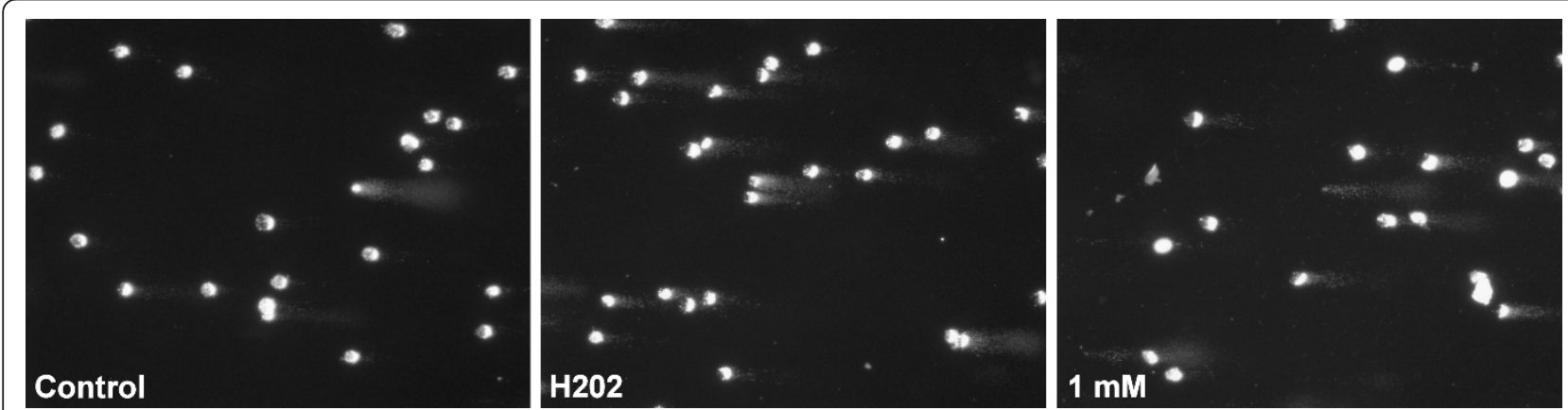

Figure 7 Induction of single- and double-stranded DNA damage in hMSC-TERT treated with GO for $\mathbf{2 4}$ h, as determined by the comet assay. The positive control was with $0.2 \mathrm{mM} \mathrm{H}_{2} \mathrm{O}_{2}$ (HP) treatment for $20 \mathrm{~min}$. Pictures were taken with a 10x objective lens. 


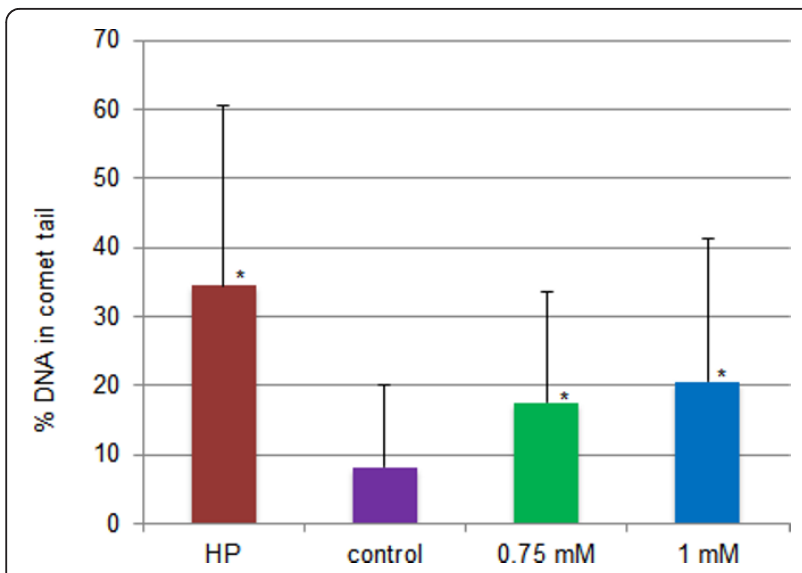

Figure 8 Extent of DNA damage measured as the percentage of tail DNA in the comet assay in hMSC-TERT cells treated with $\mathrm{GO}$ for 3 days. Cells exposed to $0.2 \mathrm{mM} \mathrm{H}_{2} \mathrm{O}_{2}$ (HP) for $20 \mathrm{~min}$, or to $0.75 \mathrm{mM}$ and $1 \mathrm{mM} \mathrm{GO}$ for 3 days were significantly different from the untreated controls, as calculated by paired t-test $(n=96$, * $=p<0.01)$. The error bars indicate standard deviation.

Impaired osteoblastic differentiation of hMSC-TERT by GO To determine the effects of GO on the osteoblastic differential potential, two markers of differentiation, ALP and MM, were analysed in hMSC-TERT cells after exposure to appropriate conditions for the induction of differentiation. The quantified activity of ALP was related to a pNP standard curve and then related to the cellular protein content of the sample in order to take the reduced growth of the GO samples into consideration. The results were normalised against the value of the undifferentiated control for comparison. The assay was performed five times representing a broad range of population doubling levels (PDL 72, 93, 95104 and 135), each performed with two replicates. All experiments showed the same tendency of significantly reduced differentiation in the GO-treated samples, despite an apparently large variation. Figure 10 shows that a pretreatment of hMSC-TERT cells with GO for 3 days reduced the extent of osteoblastic differentiation, on an average, by $61 \%$ in $0.75 \mathrm{mM}$ GO-treated cells and by $97 \%$ in $1 \mathrm{mM}$ GO-treated cells, as compared with the extent of differentiation in untreated controls.

The extent of formation of MM as a marker of osteoblastic differentiation was determined by Alizarin Red Scalcium complex formation, which was quantified by absorbance after eluting the stain with cetylpyridinium chloride (CPC). The quantified Alizarin red S staining in each sample was related to a standard curve, and then to the total cellular protein content of the sample. Figure 11 shows the microscopic pictures of hMSCTERT induced to produce MM under various conditions. A pretreatment of cells to GO almost completely inhibited the formation of MM (Figure 12).

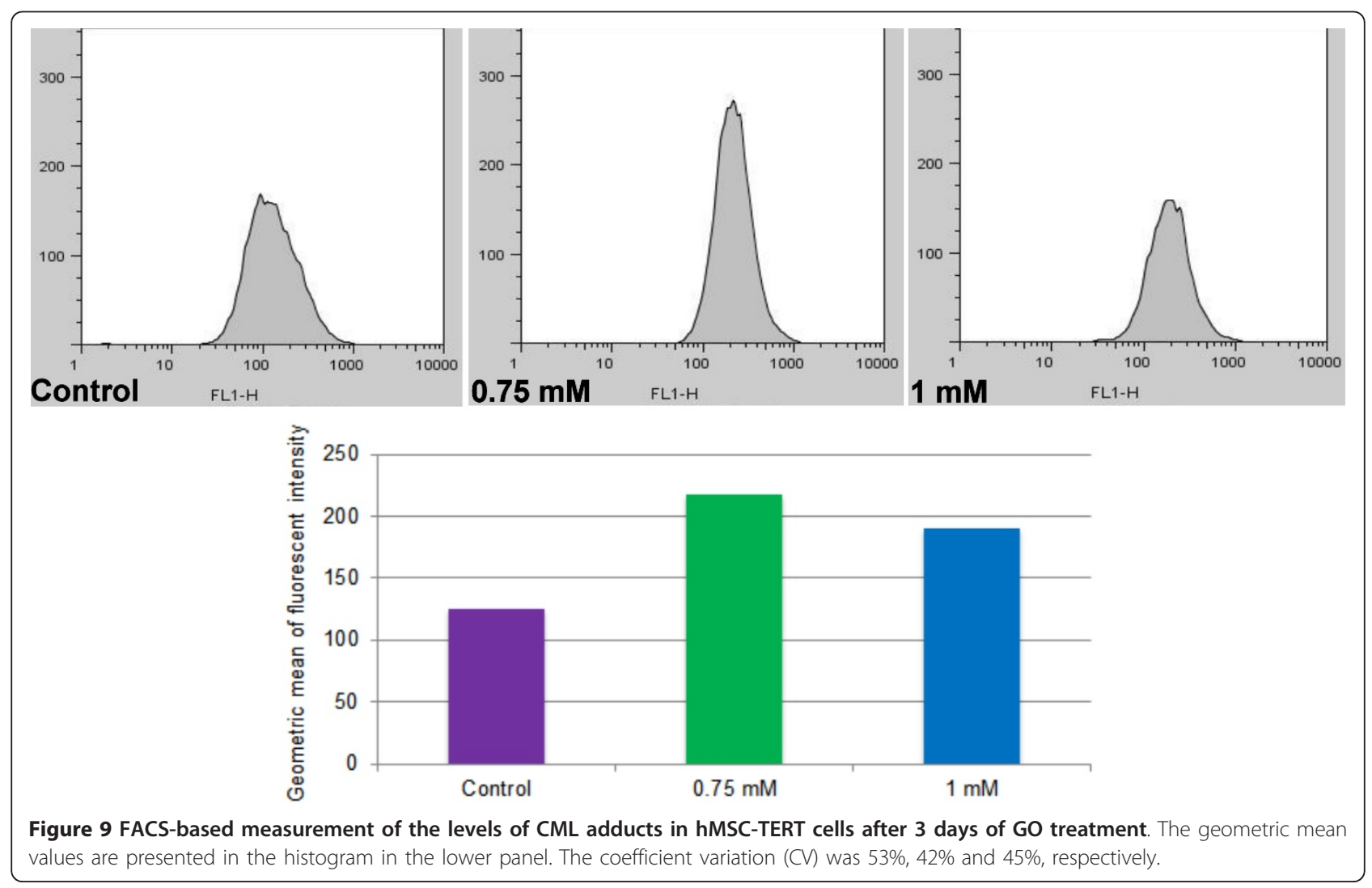




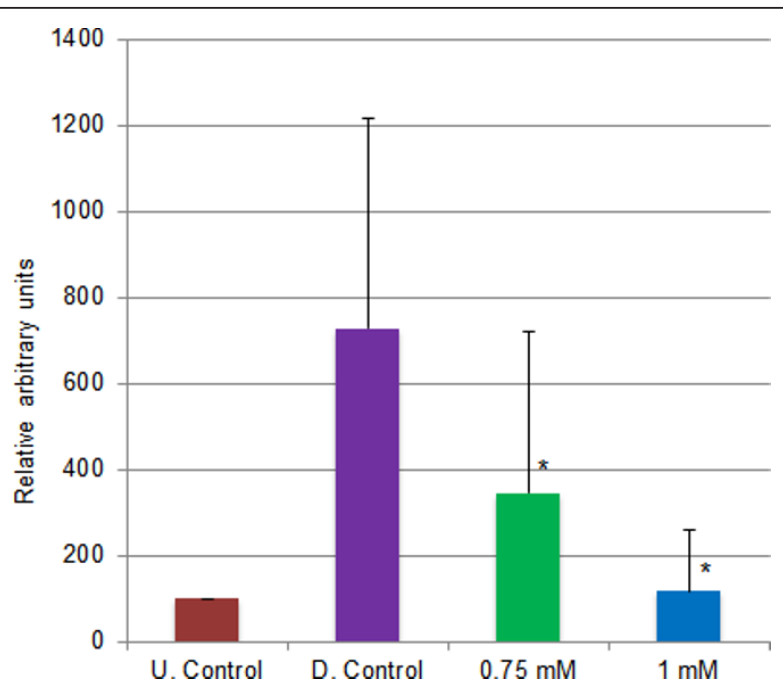

Figure 10 Effect of GO on ALP activity (relative arbitrary units) as a marker of osteoblastic differentiation of hMSC-TERT cells. ALP levels in $0.75 \mathrm{mM}$ and $1 \mathrm{mM}$ GO-treated cells were significantly different from the differentiated control as calculated by paired $t$ test $\left(n=10,{ }^{*}=p<0.01\right)$. The error bars indicate standard deviation. (D: differentiated; U: undifferentiated)

\section{Discussion}

In the present study, we have extended the previous observations made on the normal human skin fibroblasts [19] to immortalized MSC showing that the glucose metabolite GO causes molecular damage to DNA and proteins, and leads to the rapid emergence of a senescent phenotype in cells in vitro. Using a bone marrow-derived telomerase-immortalised mesenchymal stem cell line hMSC-TERT we have now shown that an exposure of cells to $0.75 \mathrm{mM}$ and $1 \mathrm{mM} \mathrm{GO}$ induces irreversible cellular senescence within 3 days. Induction of cellular senescence in hMSC-TERT was demonstrated by a variety of well established markers, such as characteristic senescent morphology and enlargement, increased vacuolisation, multinucleation, SABG activity, cell cycle arrest, and increased levels of a cell cycle inhibitor p16 [3]. The increase in the extent of single- and double-strand DNA breaks as measured by the comet assay, and increased levels of the AGE product CML in cells appear to contribute as causative agents to the GO-induced senescence among other potential mechanisms. Other studies performed on keratinocytes support our observations that GO treatment increases the level of DNA breaks [17]. Our observations of increased DNA damage and CML formation are in line with the well-established fact that increased levels of macromolecular damage, whether spontaneously accumulated during serial passaging or induced by high levels of stress, results in the upregulation of several cell cycle check point regulators $[25,29,30]$. Especially the elevated levels of p16 and p21 are characteristic markers of cellular senescence in vitro and in vivo. Additionally, p16 in particular may play a role in the initiation of the senescence programme [31,32].

Functional assays with respect to the differentiation potential of hMSC-TERT cells to osteoblastic phenotype in vitro showed that GO-treated stem cells had highly reduced ability to become functional osteoblasts, as determined by ALP activity and MM formation. It is well known that during ageing bone remodeling is significantly imbalanced, and often leads to the onset of osteoporosis [33]. The reasons considered for reduced bone formation during ageing include a reduced MSC niche, an increase in bone-marrow adiposity, osteoblastic apoptosis, and increased number of active osteoclasts [34]. As regard to the role of hMSC, studies indicate that it is primarily the decreased proliferative capacity of hMSC and the changes in the bone micro-environment which are responsible for the age-related changes in osteoblast function [35,36]. Additionally, age-related pathologies, such as imbalanced glucose metabolism leading to diabetes-2, further enhance the problems of altered bone remodeling. The results of our present study imply that an imbalanced glucose metabolism can reduce the functioning ability of stem cells in vivo both during ageing and during stem cell-based regenerative therapy.

Our study was performed with a telomerase-immortalized stem cell-line which possesses an unlimited replicative potential due to its constitutively active telomerase [21]. However, it is well known that one of the reasons for the replicative senescence of normal cells is a progressive loss of telomeres during repeated cell proliferation, associated with a lack of telomerase activity $[37,38]$. For example, in the case of normal cultured hMSC from a $33 \mathrm{yr}$ old donor, an average of 88 telomeric base pairs was lost per PD during serial expansion, leading to increased genomic instability and final growth arrest after 26 PD [39]. Furthermore, telomeres also have increased sensitivity to oxidative damage due to lack of adequate repair mechanisms in the telomere region [40]. Studies performed on other cell types have shown increased rates of telomere shortening caused by single-strand breaks when cells were treated with oxidative stressors such as $\mathrm{H}_{2} \mathrm{O}_{2}$ [41] or hyperoxia [42].

Since we had observed that GO increased the levels of DNA damage in hMSC-TERT, we made some preliminary investigations on the potential damaging effect of GO on telomere length and telomerase activity, by using a TRF assay and a RQ-TRAP assay [43], respectively. Although there was some decrease in telomerase activity, there was no detectable difference in telomere length after three days of GO treatment (data not shown). This 


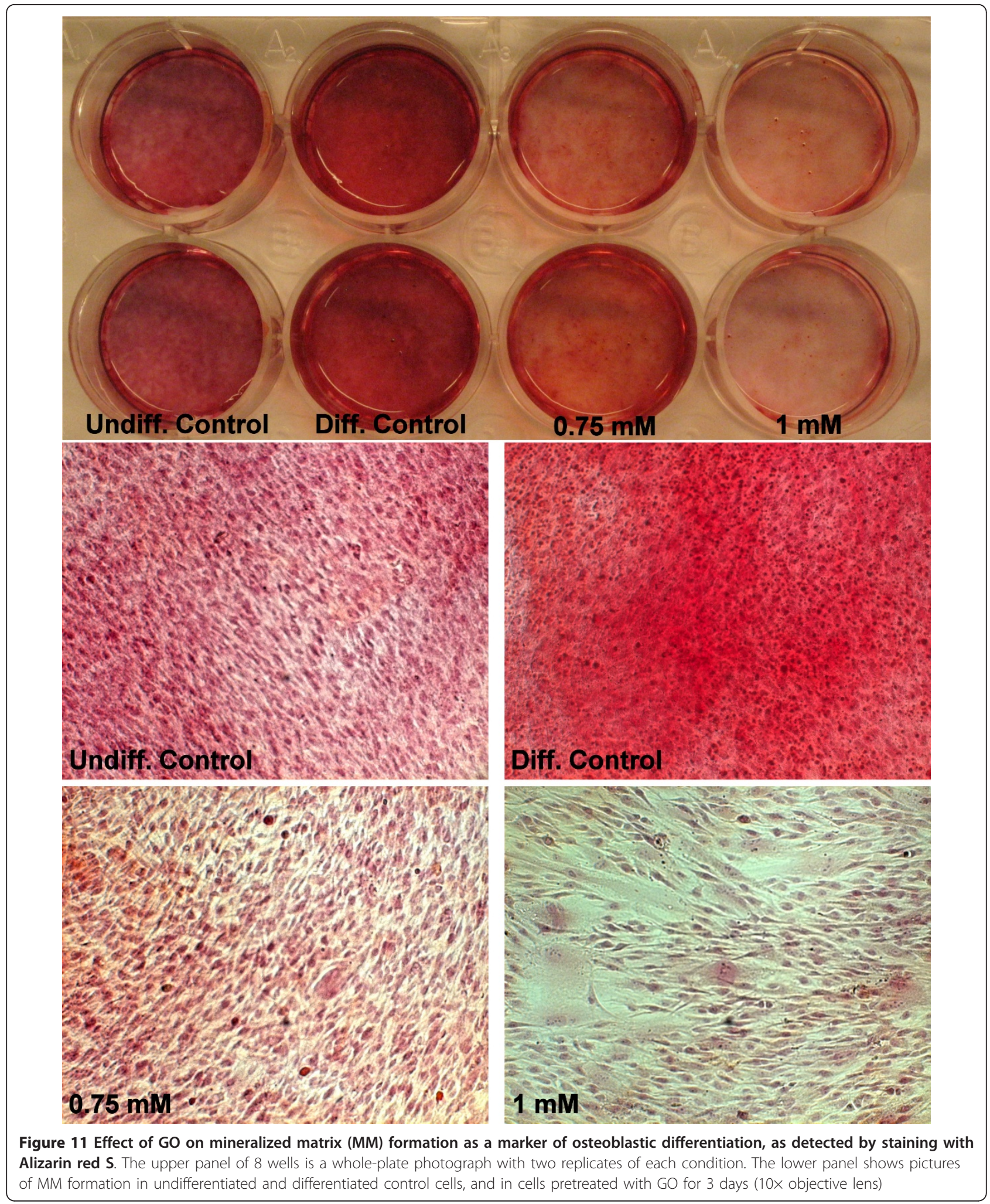




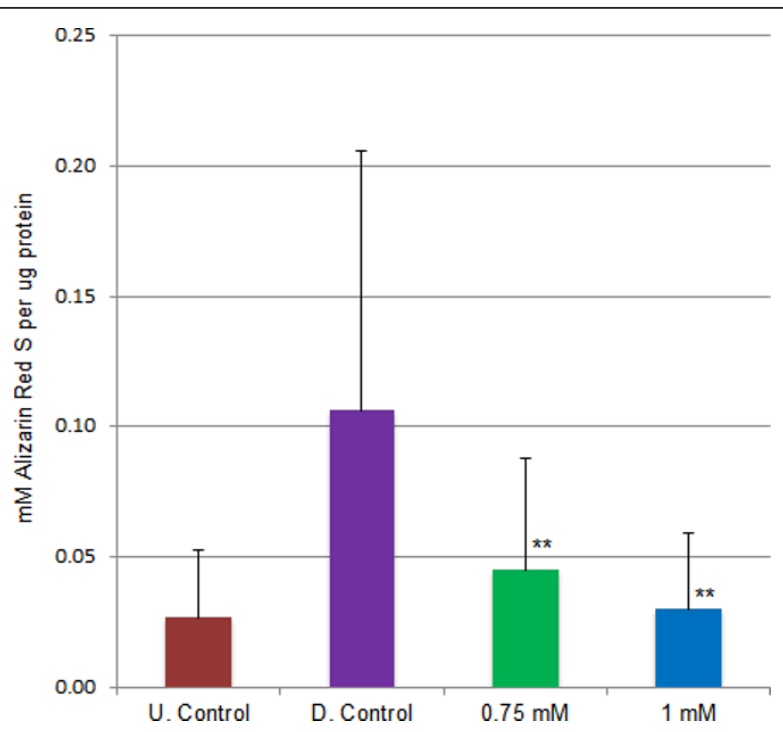

Figure 12 Effect of GO on the extent of mineralized matrix (MM) as a marker of osteoblastic differentiation. The experiment was performed 4 times, each time with two replicates. In each experiment, all values were normalised to the corresponding cellular protein content. hMSC-TERT cells pretreated with GO $(0.75 \mathrm{mM}$ and $1 \mathrm{mM}$ for 3 days) were significantly different from the differentiated control, as calculated by paired t-test $\left(n=8,{ }^{* *}=p<0.05\right)$. The error bars indicate standard deviation. (D: differentiated; U: undifferentiated)

inconsistency between reduced telomerase activity and unaltered telomere length can be explained by the fact that telomerase is constitutively and ectopically expressed in the hMSC-TERT cell line, and thus the residual activity may be sufficient to uphold the telomere length. Another reason for this can be the reduced proliferation of GO-treated cells. With fewer cycles of DNA replication less of the telomere length will be lost, despite a reduced activity of telomerase. The fact that the telomeres did not show shortening after GO treatment indicates that it did not cause significant damage to the telomeres, and so the observed GO-induced senescence can be characterized as being telomere-independent.

Based on our observations that GO can induce senescence in normal and immortalized cells, it is interesting to consider the human exposure to reactive carbonyl species (RCS) in general. The primary sources of exposure to RCS are the endogenous production or dietary uptake. The main concern of RCS is its ability to glycate both cellular and extracellular proteins, resulting in the formation of advanced glycation end-products (AGEs). Both AGE and RCS are considered to play a crucial role in several age-related pathological conditions including diabetes, Alzheimer's disease and cardiovascular diseases [13-15]. With respect to diabetes, the hyperglycemic state causes increased auto-oxidation of glucose to form elevated levels of RCS glyoxal and methylglyoxal in the blood plasma of diabetes patients [44,45], which may contribute to the long-term complications of this disease, including cataracts and atherosclerosis. The RCSs are highly capable of modifying lysine, cysteine and especially arginine residues as they do so with high reaction rates [46]. Because arginine is present in high abundance in the functional sites of many proteins, GO may disrupt their functionality by reducing enzymatic activity, receptor-ligand or protein-nucleotide binding. It may, however, be the extracellular proteins which are most susceptible to glycoxidative stress, due to their low turnover rate. Furthermore, studies performed on diabetic rats have shown a 5 -fold increase in GO-derived modification of a specific arginine in the extracellular protein collagen IV [4]. This arginine is important for the assembly and stability of the collagen IV network, which influences the thickness of the basement membrane in capillaries and small vessels. Other studies have shown that AGE-forming inhibitors reduce the formation of atherosclerotic plaques in the aortas of diabetic mice [47]. The RCS-induced formation of AGEs could thus be influencing the vascular complications observed in diabetes patients.

Besides the endogenous metabolic exposure to GO due to glucose auto-oxidation, the dietary exposure of RCS may be hazardous to human health. RCSs may be formed in large quantities during the thermal processing of foods, such as roasting, frying and baking. The levels of both GO and MGO have been found to increase with increased baking time and heat exposure in cookies [10]. Another source of high dicarbonyl exposure is the carbonated soft drinks containing high fructose corn syrup [11]. It is important to investigate if the exposure to these RCS contaminants in our diet could influence our susceptibility to age-related human diseases by inducing premature senescence in both differentiated cells and stem cells.

Finally, the results of our current study demonstrate that the glucose metabolite GO can induce cellular senescence in stem cells similar to the stress-induced premature senescence (SIPS) model [48]. Our in vitro model of GO-induced senescence in telomerase-immortalized human mesenchymal stem cells may be similarly utilized in ageing interventional studies. The combination of an immortal cell line with the ability to rapidly induce ageing at any chosen time-point, can open up several practical possibilities for testing potential ageing modulatory natural and synthetic compounds.

\section{Acknowledgements}

We thank Cristovao Lima, Alex Schmitz, Basem Abdallah, Hamid Saeed, Maria Harbo and Anders Olsen for their help and advice.

\section{Author details}

'Laboratory of Cellular Ageing, Department of Molecular Biology and Genetics, Aarhus University, Aarhus, Denmark. ²Laboratory for Endocrinology, 
Department of Endocrinology and Metabolism, Odense University Hospital, Odense, Denmark. ${ }^{3}$ Stem Cell Unit, Department of Anatomy, College of Medicine, King Saud University, Riyadh, Kingdom of Saudi Arabia.

\section{Authors' contributions}

SAL participated in the study design, performed all experiments, and prepared the draft versions of the manuscript. MK provided the cell line, some technical facilities, and participated in the manuscript preparation. SISR proposed the subject, supervised the study, participated in the study design, and in the manuscript preparation. All authors read and approved the final version of the manuscript.

\section{Competing interests}

The authors declare that they have no competing interests.

Received: 11 November 2011 Accepted: 17 March 2012 Published: 17 March 2012

\section{References}

1. Rattan SI: Increased molecular damage and heterogeneity as the basis of aging. Biol Chem 2008, 389:267-272.

2. Rattan SI: Biogerontology: from here to where? The Lord Cohen Medal Lecture-2011. Biogerontology 2012, doi:10.1007/s10522-011-9354-3.

3. Rattan SI: Cellular senescence in vitro. Encyclopedia of Life Sciences 2012, doi:10.1002/9780470015902.a0002567.pub3.

4. Chetyrkin S, Mathis M, Pedchenko V, Sanchez OA, McDonald WH, Hachey DL, Madu H, Stec D, Hudson B, Voziyan P: Glucose autoxidation induces functional damage to proteins via modification of critical arginine residues. Biochemistry 2011, 50:6102-6112.

5. Wells-Knecht KJ, Zyzak DV, Litchfield JE, Thorpe SR, Baynes JW: Mechanism of autoxidative glycosylation: identification of glyoxal and arabinose as intermediates in the autoxidative modification of proteins by glucose. Biochemistry 1995, 34:3702-3709.

6. Thornalley PJ, Langborg A, Minhas HS: Formation of glyoxal, methylglyoxal and 3-deoxyglucosone in the glycation of proteins by glucose. Biochem J 1999, 344(Pt 1):109-116.

7. Olsen R, Molander P, Ovrebo S, Ellingsen DG, Thorud S, Thomassen Y, Lundanes E, Greibrokk T, Backman J, Sjoholm R, Kronberg L: Reaction of glyoxal with 2'-deoxyguanosine, 2'-deoxyadenosine, 2'-deoxycytidine, cytidine, thymidine, and calf thymus DNA: identification of DNA adducts. Chem Res Toxicol 2005, 18:730-739.

8. Aldini G, Dalle-Donne I, Facino RM, Milzani A, Carini M: Intervention strategies to inhibit protein carbonylation by lipoxidation-derived reactive carbonyls. Med Res Rev 2007, 27:817-868.

9. Turk Z: Glycotoxines, carbonyl stress and relevance to diabetes and its complications. Physiologi Res/Academia Scientiarum Bohemoslovaca 2010, 59:147-156.

10. Arribas-Lorenzo G, Morales FJ: Analysis, distribution, and dietary exposure of glyoxal and methylglyoxal in cookies and their relationship with other heat-induced contaminants. J Agric Food Chem 2010, 58:2966-2972.

11. Tan D, Wang Y, Lo CY, Sang S, Ho CT: Methylglyoxal: its presence in beverages and potential scavengers. Ann N Y Acad Sci 2008, 1126:72-75.

12. Wolff SP, Dean RT: Glucose autoxidation and protein modification. The potential role of 'autoxidative glycosylation' in diabetes. The Biochem J 1987, 245:243-250

13. Grillo MA, Colombatto S: Advanced glycation end-products (AGEs): involvement in aging and in neurodegenerative diseases. Amino Acids 2008, 35:29-36.

14. Miyata T, van Ypersele-de-Strihou C, Kurokawa K, Baynes JW: Alterations in nonenzymatic biochemistry in uremia: origin and significance of "carbonyl stress" in long-term uremic complications. Kidney Int 1999, 55:399-399.

15. Wautier JL, Schmidt AM: Protein glycation: a firm link to endothelial cell dysfunction. Circ Res 2004, 95:233-238.

16. Kasai $\mathrm{H}$, Iwamoto-Tanaka N, Fukada S: DNA modifications by the mutagen glyoxal: adduction to $\mathrm{G}$ and $\mathrm{C}$, deamination of $\mathrm{C}$ and $\mathrm{GC}$ and GA crosslinking. Carcinogenesis 1998, 19:1459-1465.

17. Roberts MJ, Wondrak GT, Laurean DC, Jacobson MK, Jacobson EL: DNA damage by carbonyl stress in human skin cells. Mutat Res 2003, 522:45-56.
18. Thornalley PJ: Protein and nucleotide damage by glyoxal and methylglyoxal in physiological systems-role in ageing and disease. Drug Metabol Drug Interac 2008, 23:125-150.

19. Sejersen H, Rattan SI: Dicarbonyl-induced accelerated aging in vitro in human skin fibroblasts. Biogerontology 2009, 10:203-211.

20. Sejersen H, Rattan SI: Glyoxal-induced premature senescence in human fibroblasts. Ann N Y Acad Sci 2007, 1100:518-523.

21. Simonsen JL, Rosada C, Serakinci N, Justesen J, Stenderup K, Rattan SI, Jensen TG, Kassem M: Telomerase expression extends the proliferative life-span and maintains the osteogenic potential of human bone marrow stromal cells. Nat Biotechnol 2002, 20:592-596.

22. Abdallah BM, Haack-Sorensen M, Burns JS, Elsnab B, Jakob F, Hokland P, Kassem M: Maintenance of differentiation potential of human bone marrow mesenchymal stem cells immortalized by human telomerase reverse transcriptase gene despite extensive proliferation. Biochem Biophys Res Commun 2005, 326:527-538.

23. Dimri GP, Lee X, Basile G, Acosta M, Scott G, Roskelley C, Medrano EE, Linskens M, Rubelj I, Pereira-Smith O, et al: A biomarker that identifies senescent human cells in culture and in aging skin in vivo. Proc Natl Acad Sci USA 1995, 92:9363-9367.

24. Singh NP, McCoy MT, Tice RR, Schneider EL: A simple technique for quantitation of low levels of DNA damage in individual cells. Exp Cell Res 1988, 175:184-191

25. Johnson DG, Walker CL: Cyclins and cell cycle checkpoints. Annu Rev Pharmacol Toxicol 1999, 39:295-312.

26. Watson JV, Chambers SH, Smith PJ: A pragmatic approach to the analysis of DNA histograms with a definable G1 peak. Cytometry 1987, 8:1-8.

27. Bartek J, Lukas C, Lukas J: Checking on DNA damage in S phase. Nat Rev Mol Cell Biol 2004, 5:792-804.

28. Glomb MA, Monnier VM: Mechanism of protein modification by glyoxal and glycolaldehyde, reactive intermediates of the Maillard reaction. $J$ Biol Chem 1995, 270:10017-10026.

29. Kaul SC, Deocaris CC, Wadhwa R: Three faces of mortalin: a housekeeper, guardian and killer. Exp Gerontol 2007, 42:263-274.

30. Krishnamurthy J, Torrice C, Ramsey MR, Kovalev Gl, Al-Regaiey K, Su L, Sharpless NE: Ink4a/Arf expression is a biomarker of aging. J Clin Invest 2004, 114:1299-1307.

31. Haferkamp S, Becker TM, Scurr LL, Kefford RF, Rizos H: p16INK4a-induced senescence is disabled by melanoma-associated mutations. Aging cell 2008, 7:733-745

32. Baker DJ, Wijshake T, Tchkonia T, Lebrasseur NK, Childs BG, van de Sluis B, Kirkland JL, van Deursen JM: Clearance of p16(Ink4a)-positive senescent cells delays ageing-associated disorders. Nature 2011, doi:10.1038/ nature 10600.

33. Marie PJ, Kassem M: Extrinsic mechanisms involved in age-related defective bone formation. J Clin Endocrinol Metab 2011, 96:600-609.

34. Chan GK, Duque G: Age-related bone loss: old bone, new facts. Gerontology 2002, 48:62-71.

35. Stenderup K, Justesen J, Clausen C, Kassem M: Aging is associated with decreased maximal life span and accelerated senescence of bone marrow stromal cells. Bone 2003, 33:919-926.

36. Stenderup K, Rosada C, Justesen J, Al-Soubky T, Dagnaes-Hansen F, Kassem M: Aged human bone marrow stromal cells maintaining bone forming capacity in vivo evaluated using an improved method of visualization. Biogerontology 2004, 5:107-118.

37. Harley CB: Telomere loss: mitotic clock or genetic time bomb? Mutat Res 1991, 256:271-282

38. Bodnar AG, Ouellette $M$, Frolkis $M$, Holt $S E$, Chiu CP, Morin GB, Harley CB, Shay JW, Lichtsteiner S, Wright WE: Extension of life-span by introduction of telomerase into normal human cells. Science 1998, 279:349-352.

39. Baxter MA, Wynn RF, Jowitt SN, Wraith JE, Fairbairn LJ, Bellantuono I: Study of Telomere Length Reveals Rapid Aging of Human Marrow Stromal Cells following In Vitro Expansion. Stem Cells 2004, 22:675-682.

40. Petersen S, Saretzki G, Zglinicki TV: Preferential Accumulation of SingleStranded Regions in Telomeres of Human Fibroblasts. Exp Cell Res 1998, 239:152-160.

41. von Zglinicki T, Pilger R, Sitte N: Accumulation of single-strand breaks is the major cause of telomere shortening in human fibroblasts. Free Radic Biol Med 2000, 28:64-74. 
42. Honda S, Hjelmeland LM, Handa JT: Oxidative stress-induced single-strand breaks in chromosomal telomeres of human retinal pigment epithelial cells in vitro. Investig Ophthalmol Vis Sci 2001, 42:2139-2144.

43. Wege H, Chui MS, Le HT, Tran JM, Zern MA: SYBR Green real-time telomeric repeat amplification protocol for the rapid quantification of telomerase activity. Nucleic Acids Res 2003, 31:E3.

44. Mirza MA, Kandhro AJ, Memon SQ, Khuhawar MY, Arain R: Determination of glyoxal and methylglyoxal in the serum of diabetic patients by MEKC using stilbenediamine as derivatizing reagent. Electrophoresis 2007, 28:3940-3947.

45. Lapolla A, Flamini R, Dalla-Vedova A, Senesi A, Reitano R, Fedele D, Basso E, Seraglia R, Traldi P: Glyoxal and methylglyoxal levels in diabetic patients: quantitative determination by a new GC/MS method. Clinical Chemistry and Laboratory Medicine: CCLM/FESCC 2003, 41:1166-1173.

46. Rabbani N, Thornalley PJ: The dicarbonyl proteome: proteins susceptible to dicarbonyl glycation at functional sites in health, aging, and disease. Ann N Y Acad Sci 2008, 1126:124-127.

47. Forbes JM, Yee LT, Thallas V, Lassila M, Candido R, Jandeleit-Dahm KA, Thomas MC, Burns WC, Deemer EK, Thorpe SR, et al: Advanced glycation end product interventions reduce diabetes-accelerated atherosclerosis. Diabetes 2004, 53:1813-1823.

48. Toussaint O, Medrano EE, von Zglinicki T: Cellular and molecular mechanisms of stress-induced premature senescence (SIPS) of human diploid fibroblasts and melanocytes. Exp Gerontol 2000, 35:927-945.

doi:10.1186/1752-153X-6-18

Cite this article as: Larsen et al:: Glucose metabolite glyoxal induces senescence in telomerase-immortalized human mesenchymal stem cells. Chemistry Central Journal 2012 6:18.

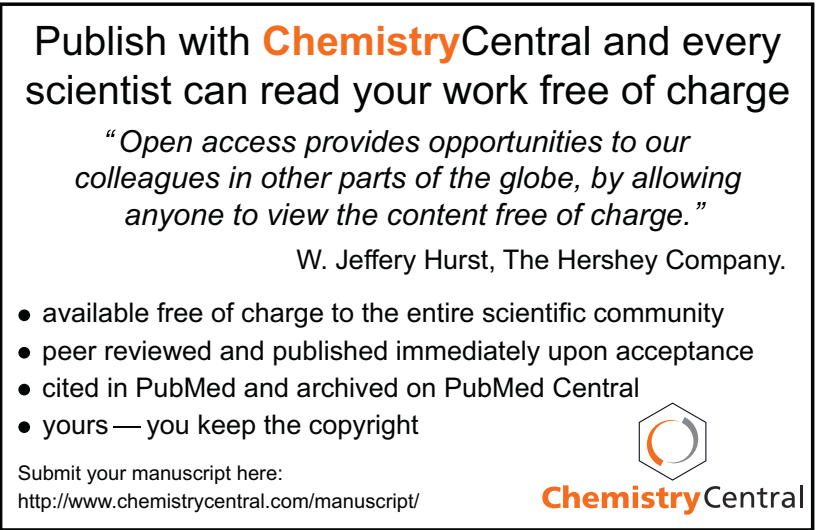

